\title{
Juncaceae fajok, mint ígéretes fenantrénforrások
}

Vasas Andrea* ${ }^{*}$, Bús Csaba, Stefkó Dóra, Kúsz Norbert, Tóth Barbara, Hohmann Judit SZTE GYTK Farmakognóziai Intézet, 6720 Szeged, Eötvös u. 6.

\section{*e-mail: vasasa@pharmacognosy.hu}

A Juncaceae család közel 500 faját hét nemzetségbe sorolják, amelyek közül a két legnagyobb a Juncus és a Luzula. Irodalmi adatok alapján a fajok fő bioaktív komponensei a flavonoidok és a fenantrének. Noha a fenantréntartalmú növényeket a népi gyógyászatban számos betegség kezelésére alkalmazzák, kémiai összetételük és hatásmechanizmusuk kevéssé vizsgált. Munkánkat megelőzően közel száz fenantrént izoláltak a Juncus nemzetség öt fajából. A vegyületek érdekes biológiai hatásaik (pl. antitumor, antibakteriális, gyulladáscsökkentő, antioxidáns, nyugtató, görcsoldó) és szerkezeti változatosságuk miatt nagy érdeklődésre tartanak számot.

Munkánk célja a Kárpát-medencében előforduló Juncaceae fajok fitokémiai és farmakológiai vizsgálata volt. Előkísérleteink során 19 faj antibakteriális, gyulladáscsökkentő és antiproliferatív hatásának szűrővizsgálatát végeztük el. Metanolos extrakciót követően folyadék-folyadék megosztással különböző polaritású frakciókat állítottunk elő, amelyeknek teszteltük farmakológiai hatásait. Elsősorban a diklórmetános és az etil-acetátos frakciók bizonyultak aktívnak. Az elővizsgálatok alapján a Juncus inflexust, J. compressust, J. atratust, J. gerardiit és a Luzula luzuloidest választottuk ki további fitokémiai és farmakológiai vizsgálatok céljára. A vegyületek izolálása különböző kromatográfiás módszerek (oszlop, preparatív vékonyréteg, gélszűrés és HPLC) kombinálásával történt. A szerkezetmeghatározást spektroszkópiai módszerekkel (1D és 2D NMR, HRMS) végeztük. Néhány esetben az abszolút konfiguráció meghatározására is sor került.

Eddig 47 fenantrént, köztük 17 új anyagot azonosítottunk a vizsgált fajokból. A vegyületek metil-, hidroxi-, metoxi-, oximetilén-, hidroxietil- és vinilcsoportokkal szubsztituáltak. A Juncus fajokból izolált fenantrének nagy része vinilcsoportot tartalmaz, így ezek a vegyületek kemotaxonómiai markerekként is szolgálhatnak.

Néhány izolált anyag jelentős antibakteriális hatással rendelkezik methicillinrezisztens Staphylococcus aureus ellen. Ezen vegyületek jelenlétét a leghatásosabb kivonatokban LC-MS vizsgálattal mutattuk ki. Az in vitro antiproliferatív vizsgálat során a junkuzol mutatott szelektív citotoxikus hatást HeLa sejteken; növelte a sejtpopulációt a G2/M és a szub-G1 fázisban, valamint gátolta a tubulin polimerizációt. A L. luzuloidesből izolált vegyületek gátolták az fMLP/CB által indukált szuperoxid anion termelődését és az elasztáz-felszabadulást humán neutrofilekben. Néhány fenantrén anti-HSV-2 aktivitással rendelkezik. 